\title{
YOUNG ACTIVISTS MAKING THE NEWS: THE ROLE OF THE MEDIA IN YOUTH POLITICAL AND CIVIC ENGAGEMENT
}

INTRODUCTION

This chapter explores the different ways in which various forms of media play a role in young people's political and civic engagement, focusing on mainstream print and television as well as the Internet. Media appear to be both an enabling and disabling mechanism for young people's political engagement. On the one hand, media provide sources of information for young people, but on the other, they can contribute to stercotypes of lazy, disinterested and disengaged youth. It is important to acknowledge the role that 'new' media, particularly the Internet, play as both a source of information and an arena for political activism. New media pose the possibility of providing a 'substitute' for more traditional forms of commentary on political engagement by young people, yet the significance of the Internet alone as a site for new forms of meaningful political and civic engagement appears to be at risk of being overstated with new media forms more likely to conform to wider political realities than to challenge them.

Our critical discussion begins with a review of the dominant conceptualisations of youth in the conventional print media. We argue that these approaches draw on different understandings of young people as 'the new generation', and of the process of social change affecting young people, and wider society. We argue that media representations of youth throughout mainstream media play a significant role in perpetuating a view of young people as lacking the political knowledge and skills to engage in contemporary political and civic action.

We continue with an examination of the ways in which discussion of young people and the media has become a meeting point for research focussing upon their political literacy, efficacy and engagement. In practice, the media (and at times researchers themselves) take up a variety of positions along a continuum. The past few years have heralded a perceived crisis for politics with some commentators suggesting stagnation in Western-style democracies. The traditional institutions of political parties and trade unions are becoming less relevant and attractive to the electorate generally, and young people in particular. This insight is given more 
currency with statistical evidence that points to falling membership and declining levels of active participation in the traditional political process (Biddle et al., 2000; Kimberlee, 2002; Fahmy, 2003; Manning \& Ryan, 2004; Henn et al., 2005 and Milner, 2005). The accompanying discourse predominantly draws negative conclusions surrounding the future of democracy and thus provides rich matcrial for critical media coverage.

An alternative view emerges however, when the focus shifts from conventional media and its representations of young people, to the uses of media by young people for the purposes of political and civic engagement. The dominant picture of pessimism portrayed through the mainstream media oullets is contrasted by the recorded rise of new and alternative forms of political activism and civic engagement that have begun to emerge. These actions are primarily driven by an agenda for change reflecting personal issues of interest and concern to young people. There appears to be a refocus of political attention. new forms of organisation, alternative models of collective action and an emerging use of new media technologies, particularly the Internet, as a source of information and a site for political discourse and mobilisation for action (Norris, 2003; Fyfe, 2004). Young people are, not for the first time, central to these exciting developments.

\section{YOUNG PEOPLE, GENERATION AND MEDIA DISCOURSES}

An understanding of both generational and social change is a key element in understanding young people's political and civic engagement. The need to take account of both generational change and the epochal transformation of the economic, social and political structures is a recurring theme within the sociology of youth (for example, Mannheim, 1953; Allen, 1968; Cohen, 1997; Wyn \& White, 1997). We illustrate the importance of this perspective through a brief discussion of the way in which mainstream media tend to draw on either one of these elements, but seldom both, to create a distorted and narrow view of young people's engagement with society.

The effect of focusing on young people's lives as simply a 'generational' change phenomenon, in isolation from the (changing) social context. overwhelmingly has the effect of casting young people as a threat to the established order. Cohen points out that this approach relies on, and perpetuates, a view of 'youth' as a category. a stage in life, which involves needs and behaviours that are common to the age group. It is seen as an important stage, not in itself, but because it is 'formative" and sets in place values and attitudes that will remain fixed in later life (Cohen. 1997, 182). The perceived danger to society is that social conventions from the previous generation may not be successfully transferred onto the next generation. If young people do not grow up to reproduce the patterns of life and the values that the previous generation did, then they appear to represent a threat to tradition and to society. This approach generates representations of young people as "threat' to established society. 
There is, however, a second theme within media representations of young people's political and civic engagement. This theme, which acknowledges both generational and social change, emphasises young people as a 'hope' for the future. We brielly discuss the nature and implications of these competing media representations of young people's civic engagement.

There is a strong tradition within youth research identifying the ways in which media have represented young people as a threat to society. Stanley Cohen (1972), describes how the media representations of young people in the 1960 s portrayed them as 'folk devils', creating what he called a 'moral panic' about youth as threat in the UK. More recently, Males (1999) has described how the US media portray young people as a threat to law and order and to the values that underpin the stability and social fabric of American life, largely through their failure to achieve the transition to adulthood in the terms understood by the previous generation. This point is also made by Smith et al. (2000), who describe how young Maori in contemporary New Zealand are frequently portrayed in the popular media as failing to make a normative transition to adulthood; as law-breakers and drugtakers. This research highlights the ways in which media discourses of youth are racialised, portraying particular ethnic or racial groups as threatening.

Recent examples of press coverage of young people and politics provide an illustration of this process. Incvitably, young people are portrayed as lazy, selfobsessed, disinterested and ignorant in relation to the political process. Melbourne journalist Suchi Das (2004) quoting Rod Cameron, managing director of ANOP, writes that many first-lime voters belong to a self-absorbed generation brought up on a diet of individualism and lack of commitment. Collectivism, he says, is anathema to their way of thinking. [Today] it's about individual effort, responsibility of self and not committing.' Das backs this up with a quote from Sarah Baldock, 18, who says of politics "I couldn't think of anything worse. It doesn't interest me at all ... I don't even understand what they are going on about.' Young people's political engagement is summed up in one article as 'don't know, don't care' (King 2005). Their ignorance of and disinterest in the formal machinations of politics receives media attention because it poses a perceived threat to the established structures and operation of democracy. Their disengagement from the political processes that they consider irrelevant is seen as yet another indicator of the failure of their generation to grow up correctly. Young people are 'blamed' for not 'bothering to listen' underpinned by a general concern regarding their apparent lack of desire to engage with, and actively participate in, the broader democratic process.

Even young people themselves will reinforce these assumptions. Rachel Sa (2004) in Toronto says she would like to challenge the media stereotype that 'some young people are lazy and ignorant' but, faced with the 'pathetic' excuses that young people come up with for not voting, she is forced to agree with them. Her solution is to exhort young people to become 'mass consumers of politics', capitalising on their positioning within mass markets, in which "the world seems to revolve around the young'. 
Periodically, alarm is raised about the lack of understanding that young people have of the formal political process and its historical antecedents. An example is provided in an article published in The Australian in August 2004, entitled 'Time to teach the lesson of democracy". This article claimed that nearly half of young 12 - 25 year olds either do not think Australia is a democratic country or have no opinion on our system of government, a finding that the author claimed was an alarming situation'. It is not clear whether the apparent lack of faith in the democratic process or ignorance was the main source of alarm, but the point of this article was to call for young people to have the basics of democracy 'drummed' into them at school. It does not appear to have occurred to this author that learning about democratic processes involves practice and active participation. As Hannam (2000) has pointed out 'learning about democracy and citizenship when I was at school was a bit like reading holiday brochures in prison.'

Furthermore, since mass opinion surveys were first used in this field during the 1940s, the findings have consistently pointed to a lack of knowledge about politics within the general population of Australia - not just young people (McAllister, 1998). For Goot (2002) 'politics, politicians and political parties have never been particularly highly praised by the Australian public' $(2002,9)$. Despite these assertions, the focus remains fixed upon the apparent disengagement of young people from conventional polities as somehow more problematic. Subsequently, governments across the world, including Australia, have responded through enhanced programmes of civics and citizenship education and countless research projects designed to identify the source of this growing apathy and to point toward a solution (for example CEG 1994; Mellor, 1998 and Mellor et al., 2002). A recent study published by NYARS concluded that the notion of young people failing to acquire sufficient knowledge from their schooling to be effective citizens has become 'a perpetual feature of the Australian social landscape' (Manning \& Ryan 2004, 100). An observation previously reported by Evans and Sternberg who argued that for young people 'citizenship has become a retro concept' that holds little meaning $(1999,109)$. They suggested that:

New vectors are needed for sharing political information. Whether this sharing takes place through the Internet, television, radio or print, young people must have relevant political information made available to them if they choose to access it. They must also be provided with the opportunity to participate in the development of ideas and information (Evans \& Sternberg, 1999, 109).

The challenge presented prompts the need for greater recognition of the potential role of young people as active agents of social and political change and producers as well as consumers of media. So what form could the proposed 'new vectors' take?

Before we consider this, we briefly discuss representations of young people as offering hope for the future. According to Lesko, there is a discernable trend for media to construct youth as a social space in which 10 talk about the characteristics of people in modernity, to worry about the possibilities of ...social 
changes' Lesko $(2001,5)$. Others have pointed out that this perspective tends to locus on girlhood as a representation of social concerns about the implications of changes in society. For example, Harris (2004) points out that contemporary sociely is characterised by dislocation, flux, and globalisation, and a demand for citizens who are flexible and self-realising, and who have the capacity for selfregulation. Modia (especially advertising) play an important role in reflecting this locus on youth as integral to the successful transition to a new social order. In her book Fufure Girl, Harris argues that young women have become integral to the social and econonic futures of Western societies. She provides evidence that a mainstream image of young women who are successful and flexible has been constructed through this process" (Harris, 2004, 151).

This perception is backed up by recent media coverage of young women who are engaged actively in the political process. The article 'At 23, Clare the Mayor makes Australian history' covered the election of the youngest female mayor in Australian history (Nguyen, Boulton \& Millar, 2004). The article draws inspiration from similar achievements in the recent past including the 1999 election of Janie Dickinson as mayor of Launceston at the age of 27 . The printed media has also focussed attention upon young people campaigning for and taking up positions in political office, Both The Age and Herald Sun featured articles on Jess Healy, aged 19, who lead the Democrat's Senate ticket in 2004 (Hudson 2004; Protyniack 2004). In November of the same year Trudi McClure was elected to The City of Bendigo council at the age of 24 prompting the headline "Young and elected? Yes, it's Trudi' (Khadem, 2004). While young women did appear to feature strongly in federal and local elections, at least one young man was also elected. Miller (2004), also reporting in The Age penned the headline 'Top local government job goes to 24-year-old' on the appointment of young Monash Mayor Geoff Lake to the position of president of The Municipal Association of Victoria, defeating 7 other candidates to win the position.

The media also represent young people as workers in the new economies, and as symbols of a changing society. The new technologically- and entrepreneuriallysavvy generation are seen as 'more diverse than boomers ... more cheerful than their oider siblings' and as overwhelmingly optimistic' (Ellingsen, 2000, 4). From this perspective, media in Australia and other western countries do seek young people's views and occasionally they are acknowledged as a potential political force. Curtis (2004), writing about young people in the UK, asserts "perhaps if they were better represented, young people could become more engaged.'

The Herald Sun asked young Victorians about their views on voting in the lead up to the last federal election, finding that "Gen $Y$ rates honesty as the most important quality in a prime minister", and the majority of young people stated that 'all political leaders were out of touch with their concerns' (O'Neill, 2004), Beth O'Connor, 18, is quoted as saying: 'I find it really complex and boring. I'm not educated well on it. I think politics should focus more on our age group. We've never voted before so we have no idea, so if they wanted us to vote for them, we'd be an easy larget.' 
This point is taken up by Castles (2004), who argues that the Government doesn't know what issues the young face and isn't interested in linding oul'. The point that young people have a low level of engagement in mainstream politics is seen as a lost opportunity - a failure, not on the part of young people but on the part of a broader process that is out of touch with the concerns and aspirations of the political generation. Castles was one of the few journalists to take issue with the Australian Prime Minister John Howard's stated plan to close the electoral roll as soon as the next election was called. The main effect of this would be to deny thousands of young Australians an opportunity to register to vote. further compounding their evident alienation from this aspect of the political process. Castles' article focuses directly on the impact of social change on young people. challenging politicians to "picture the world through an 18-year olds eyes'. He asks "what's it like to:

- know that no amount of education will guarantee you stable employment?

- hear everyone talking about security, and yet feel so insecure?

- have elders talk about the benefits of work for the dole for you. not for them?

- have a mobile phone bill you can't possibly pay?

- be gay, knowing your Prime Minister would be disappointed if his child was the same?

- have a million options and yet feel you have none?

- feel priced out of higher education because you lucked out in a generational lottery?

- know you will pay rent forever?

- know your generation is exhibiting signs of depression up to 10 times that of previous generations?

- know that the current Government would rather you were off the electoral roll than on it?' (Castles, 2004).

Louise Merrington, one of the lew young people to have their views represented in the mainstream media in the lead up to the 2004 Australian federal election proposes an answer. Merrington (2004), writing in SAGE. (The Age's student newspaper) takes issue with the constant branding of young people as politically apathetic. She suggests that 'it is important to distinguish between apathy and disillusionment.' Reinforcing the point made by Castles, Merrington aroues that "with so little emphasis placed on youth issues, young people are naturally becoming disillusioned. It is very difficult to develop strong feelings for a political party when, frankly, we are given no reason to." Merrington takes strong exception to the negative stereotypes that are constantly perpetrated about young people in the media and suggests that the youth problem will not be solved by black-listing a generation.'

Merrington also refers to one of the most significant effects of social change on 
young people's engagement with political activity. Perhaps the older generation is looking in the wrong direction. Merrington suggests:

Look inside and you will find that, contrary to popular opinion, young people are not only thinking about, but actively working 10 address issues within the local, wider and international communities. From students talking about their experiences of racism, to surviving year 12 , to working with the elderly and disabled, to helping starving children in Africa, young people are engaging with the world with passion and commitment (Merrington, 2004).

In effect, Merrington is drawing our attention to the way in which a new generation is responding 10. and shaping, social change (Dwyer \& Wyn, 2001). We argue that a full understanding of the role of media in young people's political and civic engagement requires a shift of perspective which recognises the impact of social change on our lives, and especially on the lives of the young.

By way of a summary, Figure 1 presents an overview of the key elements of our argument. Our analysis so far has identified the competing discourse of young people's civic and political engagement represented through the dominant media paradigms premised upon the respective notions of hope and threat. The lives and lifestyles of young people are contextualised within the often exclusive frameworks of social and generational change. Corner and Pels (2003) argue that the majority of studies surrounding media-politics relations can be categorised into two perspectives namely, enabling and disabling. The enabling paradigm is characterised by media that portrays young people as active agents of social change and provides a platform for the presentation of factual knowledge around political issues, as well as offering a vehicle 10 advance and sustain democratic participation.

Conversely, within a discourse of threat, a disabling media for the most part dwells upon the civic and political disengagement of young people, subsequently promoting negative stereotypes. Young people's potential political agency is caught up in wider media coverage affected by journalistic styles influenced more by spin, scandal and sleaze than positive social change affected by young people's participation. A media paradigm with added concern for notions of 'celebrity' as a gauge of political efficacy may in effect contribute further to the perceived disengagement of young people from civic and political life, thus undermining their relationship with democracy.

In terms of the challenge ahead, Davis reminds us that:

Serious attempts to engage with youth culture are few and far between in the mainstream media, even though they are largely run by people of a generation who voiced similar complaints twenty or thirty years ago. It's barely possible to open a newspaper now, or switch on a TV show or listen to radio, without coming across some paean to a misremembered past (Davis, 1997, 101). 
Figure 1. Media, young people and politics - an overview

\begin{tabular}{lll}
\hline $\begin{array}{l}\text { Representation of } \\
\text { Youth }\end{array}$ & Discourse of Hope & Discourse of Threat \\
\hline Context & Social Change & Generational Change \\
Media perspective & Enabling & Disabling \\
$\begin{array}{l}\text { Perceived relationship to } \\
\text { democracy }\end{array}$ & $\begin{array}{l}\text { Media seen as a necessary } \\
\text { agent of popular democracy }\end{array}$ & $\begin{array}{l}\text { Media seen as having a } \\
\text { propensity lo undermine } \\
\text { democracy }\end{array}$ \\
$\begin{array}{l}\text { Media as a source of } \\
\text { knowledge }\end{array}$ & Circulates knowledge & $\begin{array}{l}\text { Substitutes entertainment for } \\
\text { knowledge }\end{array}$ \\
$\begin{array}{l}\text { Media view of youth } \\
\text { agency }\end{array}$ & Civic engagement - young & $\begin{array}{l}\text { Civic deficit -young people } \\
\text { as apathetic and disengaged }\end{array}$ \\
Media reporting style & Presenting Truth & $\begin{array}{l}\text { Perpetuating Myth and } \\
\text { Stereotypes }\end{array}$ \\
\hline
\end{tabular}

Figure I (Adapted from Corner \& Pels. 2003)

Rather than demonising young people for failing to grow up in the way that the previous generation did, or romanticising young people as the hope of the future, we suggest the need to rethink young people's engagement in civic and political processes in the light of changing times. We now turn out attention to questions surrounding the role of the media as an arena for nurturing political literacy and a vehicle for the active political engagement of young people.

\section{THE MEDIA AS A SOURCE OF POLITICAL KNOWLEDGE}

The relationship between young people, politics and the media has become a new meeting point for research. A key focus for recent investigations across many Western countries has been the impact of media as a source of information on social and political issues and a platform for the subsequent development of political knowledge for young people. A snapshot of some recent studies designed to assess the significance of media in the acquisition of political information and knowledge for young people provides some insight to this relationship.

An Australian study of 633 year 11 students conducted in the state of Victoria revealed that television was used much more than any other form of news media as a source of information about current affairs. A national Australian study highlighted that $50 \%$ of a sample of 14 year old students felt that lollowing political issues in the newspaper, radio or TV was important for good citizenship. A point noticeably taken on board by teachers surveyed in the same study who "use media more than any other resource in teaching civic related topics'.

The IEA study of 14 year olds across Europe found that in almost all countries. news broadcasts on television were the most prominent source of political 
information for young people. The study concluded that watching television news programmes had a positive eflect on civic knowledge in about half the countries. A follow up study of upper secondary students revealed a similar pattern. In 10 European countries over $90 \%$ of the students stated that they 'sometimes' or 'olten' watched television news. An American study on what democracy meant to Grade 9 students found that television was again the primary source of media accessed to ohtain information on politics. This was reported by $79 \%$ of the sample, far outweighing the importance of newspapers and radio.

Nevertheless, this evidence should conceivably be approached with some caution. A common limitation of the studies cited is the priority given to questions surrounding the impact of the mainstream or mass media. Other similar studies have adopted a somewhat broader understanding of media. A recent research project in the UK with a sample of 914 young people aged between 11 and 18 also found that television news was the main media source of political knowledge followed by newspapers, radio the Internet and magazines respectively.

$\begin{array}{lclcc}\text { T.V. News } & \text { Newspapers } & \text { Radio } & \text { Internet } & \text { Magazines } \\ 83 \% & 69 \% & 63 \% & 48 \% & 36 \%\end{array}$

Source: (MORI, 2003).

These lindings are mirrored in another UK based study. In response to the question where do young people get information about politics and politicians? a sample of 102014 to 19 year olds presented the following responses:

$\begin{array}{cclcc}\text { T.V. } & \text { Newspapers } & \text { Radio } & \text { Internet } & \text { Magazines } \\ 62 \% & 55 \% & 15 \% & 12 \% & 6 \%\end{array}$

Source: (CYPU, 2002).

The apparent importance of television as a source of political knowledge is given further support where young people have been asked to consider their levels of trust in the media. Once again, television news appears to outperform the other mainstream sources. Kerr et al. found that for a sample of English school students news broadcasts on the television attracted the most positive response with $56 \%$ trusting them 'quite a lot' or 'completely', followed by news on the radio polling $31 \%$ then newspapers with $14 \%(2003,78)$. The researchers also concluded from the young people studied, perhaps unsurprisingly, that those who spent longer each evening watching the television were significantly more likely to trust the television news. Similarly, MORI reported that $45 \%$ of the young people involved in their study would trust television newsreaders to tell the truth compared to $13 \%$ in support of press journalists. Politicians generally were seen as trustworthy by only $18 \%$ of the cohort sampled.

The overall trust in media compared with other sources of information about politics is further highlighted by the recent Australian study of youth and citizenship conducted by Manning and Ryan. The most trusted source was teachers 
$(75 \%)$, marginally ahead of family $(73 \%)$. Friends were next with $54 \%$, lollowed by the media $(36 \%)$, then politicians $(34 \%)$. Interestingly, respondents from a sample of Indigenous young people found the media the least trustworthy source of all these options.

A trawl of recent studies suggests that despite the growth of new electronic technology particularly the prevalence of the Internet, the fact remains that mainstream media, and in particular the television, still appear to be major sources of information and knowledge around social and political issues for young people. For example, in a recent study conducted in the USA it was found that even with $31 \%$ of young Americans accessing the Internet 7 days a week, television remains their preferred method of obtaining news and information with $46 \%$ watching television news at least 4 days per week.

Taking an objective view, it is perhaps arguable that these conclusions may also reflect the dominant academic concerns for research on the civic and political engagement of young people. An agenda often subjugated by a paradigm that persists in limiting investigation to the explicit relationship between young people. conventional politics and the mainstream media. A similar dispute is put forward by Coleman and Rowe who propose that the political and media elite themselves 'have yet to adapt to the age of digital interactivity' $(2005,13)$. They go on to suggest that the Internet not only endows young people with new digital skills but also new ways of interacting with information and knowledge. This claim is given further substance by a recent Australian study that surveyed a sample of young people aged between 15 and 30 about their perceptions and use of media. The survey found from the 733 respondents that they consume media in a variety of forms but 'particularly the Internet', to which many lurned to as their first choice for information

We are given the impression from these arguments of a potentially new focal point for research, analysis and understanding of the changing nature of the correlation between young people, politics and the media. In an attempt to further explore the role of the media as a catalyst for youth engagement, we have drawn upon the emerging qualitative data from the ongoing Leaming for Activism project: a study of the lives of young people living in the state of Victoria who are actively engaged in civic and political life.

\section{THE MEDIA, CIVIC AND POLITICAL PARTICIPATION - STORIES FROM YOUNG ACTIVISTS}

At the heart of the Learning for Activism project (reported earlier in Fyfe. 2004 and Fyfe, 2005) is the concept of political literacy, which is viewed as the composite effect of knowledge, skills and values on young people's predisposition to become politically active. For Cassels and Lo (1997), the media plays a signiticant role as a socialisation agent in the development of political literacy. Earlier work by Crick and Potter suggested that the achievement of political literacy should not be viewed as a passive experience, but rather as an active learning process that supported potential social and political actors (in this case young people) to relate their understanding of issues towards praclical participation. in other words creating a 
'proclivity to action' (Crick \& Potter, 1978, 41). This notion of transmission from learning to action is supported by Moodley and Adam who argue that political literacy results in active citizenship' $(2004,165)$, perhaps suggesting a correlation between the acquisition of the compound of knowledge, skills and values with political and civic engagement.

By accessing the accounts of the young activists involved in the Learning for Activism project, we are offered some insight to the significance of the media as a source of political literacy and as a trigger for action. What we find from the emerging data is tangible support for some of the findings of the related studies discussed above. The mainstream media, particularly newspapers together with current alfairs and news programmes on TV, are identified as key sources of formative political knowledge.

the first time I ever became interested in politics .......I was watching the $\mathrm{ABC}$ news with my parents which we did most nights...I discovered the newspaper. I'm from a small country town, so I had that local paper, but I wanted more so I got the national papers and started reading those. (Male, 22, member of Australian Labour Party)

I think I've always had an interest in politics... I grew up on a cattle property in Queensland....my only link to the world was through the television. And I actually liked watching the news a lot so I think that sort of sparked my interest seeing what was happening in the world. (Male, 24, member of Liberal Party)

I watched for the first time this programme on SBS called Insight ......here were all these people who were around my age and they had all these views and they were talking about things that l'd never really heard of and I thought oh, maybe I should know about this stulf. (Female, 19, Fair Trade \& Environmental activist)

The mainstream media is also credited with forging political ideology, albeit mainly uncontested and biased, by the underlying editorial position of specific newspapers.

I guess because of my readings and stufl in the Herald Sun at the beginning I was very hmm, right wing and sympathetic towards conservative political interests and so, even without knowing that I was specifically liberal or whatever that's what my conception was...I think at the same time my thoughts were very superficial and it was just what the Herald Sun was telling me I didn't really go into the depth of the ideology behind it. (Male, 19, Fair Trade Activist)

I was 18 or 19 and I hadn't yet twigged that just because the newspapers say that its true means its true... I'd considered myself quite informed at that stage but I was only relying on I suppose the Courier Mail. (Female, 23, Green Party Member) 
Moving outside the common terrain of the researeh projects discussed earlier, we begin to gain a fuller picture of the diversity of media aceessed and the often complex nature of the relationship between media and the range of political activities of the cohort studied. Those young people involved in political groups and organisations deemed outside of the recognised mainstream Australian political parties gave more credence to "alternative' printed media as an inspiration for their journey into political life.

my final year of high school...I picked up this magazine called Adbusters at the newsagent....I was always interested in politics and stulf but never sort of interested in changing it or doing things about it that was when I changed things. (Male, 19, Fair Trade Activist)

I started campaigning with Green Left Weekly, even though I wasn't a member of any organisation I just thought that Green Left was such an awesome paper and an awesome resource that I wanted to get it oul to as many people as possible. (Female, 23, Socialist)

The Internet is cited on several occasions not only as an additional source of intormation but also a platform to seck and express counter opinion. Specific sites such as Indymedia (www.indymedia.org) were seen as reliable in content but also appealing in style. There was a genuine sense of ownership and collective identity generated by peer run youth websites (such as www.tibewichent) and a fecling of solidarity between those young people active as online bloggers. One young blogger interviewed identified herself as a journalist with a clear social purpose to challenge what she saw as the rhetoric of the mainstream media through her daily postings. It was her view that:

most people just seemed to go with the opinion they re led on 7 News or from The Age and don't take it any further than that. And I think that a lot of times its because well they don't realise that they should question it which really you can't blame people for you should be able to trust your media but the fact is that you can't and you need to look at 4 or 5 sources and make your own mind up. So yeah that is my primary goal is just to have people be informed, know what's going on even if you don't watch the news. (Female. 23, Environmental Activist)

The emerging findings of the Learning for Activism project point towards the obvious influence of the media as a varied source of information and knowledge on political issues for young people. For these young activists, media coverage of political issues and events was instrumental in generating their formative interest and understanding.

We have focussed our attention on the potential of the media in nurturing interest, providing information and prompting active participation. For some. however, the prevalence of the media in the lives of young people is seen as a potential risk to the future of democracy. The fact that for many young people the television media remains a consistent source of information on social and political issues, has in turn generated a new genre of viewing choice that is seen by many 
other media commentators as a further threat to the political and civic engagement of young people.

\section{YOUNG PEOPLE. THE MEDIA AND THE VOTING PARADOX}

A recent article in the UK Daily Telegraph published findings of a research project conducted with young people aged 18 to 22 reporting that fewer than $42 \%$ of firsttime voters in the forthcoming British General Election thought that they would vote for a political party, yet $46 \%$ had already cast a vote for contestants in a reality TV show (Thomson, 2005). The same research prompted The Scotsman newspaper to run with the headline 'Reality TV beats politics for most young people' (Woodcock 2005). This emerging phenomenon is described by Corner and Pels as the "Voting Paradox" (2003). The potential outcomes of the alleged voting paradox were investigated further in a UK study conducted for Demos. As one 17 year old from London said:

When I vote in Pop Idol, something actually happens. I liked Will so I voted for him every week and eventually he won. With politics, l'll get the chance to vote once every four years, then I'll probably have to wait another four ycars to see if it actually makes any difference, and half the time I don't think it will (Howland \& Bethell, 2003, 52).

For this particular young person there appears to be tangible change generated from them exercising their vote for a preferred Pop Idol. However, there is very litte that can be gleaned from the outcome to inform our understanding of the political connectedness of young viewers of reality TV. Earlier research undertaken by Buckingham (1999) around the relationship between young people, politics and the media found that the perceived disconnection of young people from conventional politics was borne out of an attitude of cynicism rather than the dominant media assumption of apathy. As Buckingham states:

Politicians were often condemned, not merely as boring, but also as corrupt, uncaring, insincere and self-interested; and politics was widely dismissed as a kind of dishonest game, which had little relevance to the students' everyday lives and concerns (Buckingham 1999, 176).

The cynicism expressed by the young cohort studied reflected their ability to read the media representations of politics with a critical view leading not only to an understanding of the issues presented, but also an awareness of media manipulation. For Radford (2003), the manipulation that we are routinely exposed to through the media is 'a threat to democracy' (2003, 315). Buckingham also suggests that the cynicism highlighted in his study was also a result of 'young people's growing awareness of their own powerlessness' that was magnified under a generational lens that measured their maturity against adult orientated standards (1999, 176). Ironically, perhaps, information gained through the media had the subsequent effect of young people in turn challenging the perceived inconsistency and hypocrisy of adults, including politicians. 
In relation to the idea of an assumed voter paradox, Corner and Pels (2003) make similar observations. However, they propose that the perceived political cynicism or civic withdrawal displayed by many young people might be more often a rejection of traditional political divisions and of arrogant, distanced and self-absorbed politicians. On the whole, the sentiment is similar. The notion of the voter paradox goes some way to affirm the complexities of the role of the media as both an enabling and disabling vehicle for the political engagement of young people. The role of the media in reporting politics appears to enhance young people's knowledge, skills and values, the core elements of political literacy. Equally, it appears to play a major part in fuelling levels of cynicism and subsequent apathy and disengagement.

It is also noteworthy that the disabling form of media coverage is not exclusive to young people's engagement with representative democracy. All too often their involvement in alternative forms of participative and direct political action is met with ridicule and doubt. During the worldwide demonstrations against the armed invasion of Iraq in 2003, young people were actively involved in large numbers of demonstrations across Australia. Rather ironically, some politicians dismissed the ir collective organisation and participation. Quoted in The Australian, New South Wales Premier Bob Carr said he would not support future marches unless some young people whom he described as "extremists' and 'political exhibitionists" were not involved (Harris, 2003). Other media reports of young people's participation in the anti-war demonstrations framed their actions as criminal. once again promoting a discourse of threat and deviance rather than support for their civic and political engagement (Tarabay, 2003).

Despite the inconsistencies of the media portrayal of young people's political participation, they continue to be at the forefront in the developments of innovative forms of political organisation and engagement, subsequently forging alternative relationships with the media. In light of this, we now refocus upon contemporary advances in media and communication technology in an attempt to identify their impact on the civic and political engagement of young people.

\section{ELECTRONIC MEDIA - A NEW VECTOR FOR POLITICAL ACTIVISM?}

The contemporary generation of young Australians are living in a time of accelerated and unprecedented technological change. The pervasive nature of media has impacted upon the realms of their everyday lives. Media provides potential 24-hour worldwide communication through the Internet. Instant access to world events is made more possible by constant television coverage enhanced by satellite and cable systems (Rodgers, 2003). In international terms, 53\% of Australian households now have Internet access, compared to $67 \%$ in the USA and $45 \%$ in the UK (NetRatings, 2005, 2). The ownership of mobile phones by Australian children doubled between 2001 and 2003, the biggest growth over that period being $57 \%$ among 10 to 14 year olds (Quantum Market Research, 2003). These trends look set to continue. Indications are that the new generations of young people are engaging with new technology from a younger age than the previous 
generation. A recent study conducted on behalf of the Australian Broadcasting Authority found that from a sample of children between the ages of 6 to 17 , within the 8 and 9 year olds, one third had started using the Internet at age 5 or 6 . Of all the participants in the study, $37 \%$ accessed the Internet on a daily basis (NetRatings, 2005, $\mathrm{x}$ ).

As a media form, the Internet is immediate, interactive and international. It provides a vehicle to generate new and alternative knowledge and information. Additionally, it offers scope to create broad international alliances within a new infrastructure for political activism that ignores geographical boundaries and challenges conventional political structures and process (Rodgers, 2003; McGaughey \& Ayers, 2003). The growing interest in the impact of globalisation and new forms of technological communication have resulted in young people becoming some of the key protagonists of new and alternative forms of collective online political activism that have been by their very nature creative and innovative (Koffel, 2003). Young people are already at the forefront of utilising new forms of media. Web-based discussion groups, blogging and peer-run web sites (such as wwa vibewirenc1) have given young people both access to alternative forms of information and new knowledge through electronic interaction and debate in emerging 'cyber' communities. From the findings of a recent UK study, Coleman and Rowe conclude that:

Young people are using the Internet in a variety of ways to find their way into complex discourses of adult politics, but as they do so, they weave innovative networks of civic connection which both refresh and reshape the civic and political landscape ( Coleman \& Rowe, 2005, 14).

As an alternative media form, the Internet appears to provide an arena for the development of the knowledge, skills and values that not only enhance young people's levels of political literacy but also offers a potential platform for online organisation and ensuing active participation. So what are some of the drawbacks?

\section{NEW MEDIA, NEW ACTIVISM - SOME NEW PROBLEMS?}

As a source of alternative information and a site for political activism, the Internet also presents a number of potential problems. There appears to be little or no mediation of the content. As a result, the virtual landscape equally offers up space for posting alternative information and forms of activism that pose a potential threat to groups and individuals in the wider society. For example, organisations that are overtly racist or support terrorist activities are adopting similar tactics to present their agenda for change, recruit support and mobilise for action (McGauchey \& Ayers, 2003). Consequently, the Internet cannot be assumed to be an inherently unifying technology or a reliably objective source of information and discussion when it also operates as a potential platform for extending political networks that may promote discrimination and social injustice.

Across the range of websites designed to support political activism, the style and content is often random and inconsistent (Neuman, 1998 and Norris, 2002). Whilst 
the Internet contains a wealth of information, a prerequisite for any "surfer" is the possession of the technical skills and know-how to lind what they are looking for. knowing where to look and how to navigate towards a specific location in the ever expanding virtual world. The perennial issue of the digital divide continues to present barriers to participation for large numbers of young people limiting the possibilities of reaching some of those most affected by the very issues being addressed through campaign activities (Rodgers, 2003).

There is conceivably a potential risk that the role of the Internet as a source of political knowledge and an impending site for activism is becoming overstated. The Internet appears to tender no guarantee of introducing new actors - including young people - to the broader political arena. Scott and Street (2001) challenge the emergence of any new political culture claiming that 'the 'newness' refers to the details of political practice rather than marking any more fundamental change' $(2001,33)$. The prevalence of online discussion through forums, chat rooms and blogs undoubtedly opens up alternative sites for political discourse but this does not necessarily lead to any meaningful shared collective identity, organised networks or strategies for action, which for Van Aelst and Walgrave (2004) are some of the core characteristics of collective social movements. There also appears to be little evidence to suggest that electronic activism alone has radically challenged existing power structures or that there is any sense of a stable long-term political movement emerging or any massive political change in sight (Dahlgreen. 2003). The new technology provides novel means to organise, mobilise and communicate yet Burgmann observes it has not displaced older forms of organisation, mobilisation and political communication' $(2003,297)$.

All told, our critical analysis is leading us loward suggesting that the so-called technical revolution is at the very least generating the possibility for a realignment of the role of the media in relation to young people's civic and political engagement. The possibilities offered by the discourse of hope shifts the priorities of media attention toward a more sympathetic coverage of the potential role of young people as social and political actors. In contrast to the dominant view of young people suffering from the malaise of a perceived civics deficit or incapacitated by cynicism or apathy towards the political process, there is a required shift to a media that acknowledges their democratic participation. A further development would be the recognition of their dual role as both consumers and creators of media in such a way that it potentially challenges the prevalence of the disabling paradigm, a point amplified by Burton who argues that:

Young people want more opportunities to create their own media and to express their views as important members of civil society...... Today's young people, unlike previous generations, consider that the media intersects just about every physical and emotional space of their lives and they are discovering their own emerging place within that landscape (Burton, 2000 , 62). 


\section{YOUNG POLITICAL ACTIVISTS MAKING THE NEWS - SOME CONCLUSIONS}

Media play a complex role in both facilitating and disabling young people's political and civic engagement. Young people gain information about political issues and processes from media (and increasingly use new media such as the Internet for this purpose), but at the same time, media play a significant role in perpetuating disabling stereotypes about young people and their political engagement.

In drawing selectively on conceptions of youth that emphasise generational change or social change but seldom both, media tend to contribute to a polarised representation of young people's political and civic engagement. Focusing on gencrational change, in isolation from the changing social context, young people are readily represented as apathetic, disengaged and as a threat to traditional political process. These views fail to take into account the dramatic changes in life patterns that have occurred over the last 25 years, and the extent to which traditional (formal) political processes and preoccupations in many Western countries simply ignore the effects of changing economic realities on young people's lives. As many young people remind us, from their point of view it is the politicians who are disengaged and apathetic and all too often the issues that concern young people, including the costs of education and health, unemployment and the cosis of accommodation are not prioritised on the political agenda.

But it is not simply a matter of focusing on social change either. The representation of young people as the masters of new technologies that facilitate innovative forms of political engagement runs the risk of romanticising young people's political and civic participation. The evidence suggests that while new media such as the Internet undoubtedly have the potential to affect the direction and outcomes of political activism at all levels, in itself this does not necessarily ensure political action or civic engagement. In other words, the Internet should not be seen as an obvious nor unique site for political action, but more an additional source of information and a platform for critical discussion and organisation.

Perhaps the essential role of Internet activism is as a complementary approach within the wider spectrum of democratic participation. As the emerging data from Fyfe's study of young activists in Australia illustrates, young people's central role in the development of new forms of media sits alongside their influence in redefining the boundaries of civic and political engagement where they are extending the possibilities for collective action that attracts positive 'mainstream' media coverage, whilst at the same time generating new media forms.

Rather than dwelling upon notions such as the 'voter paradox' that merely reinforce the perceived apathy and disengagement of young people from traditional politics, we might recognise the Internet and other forms of new media as an innovative and creative arena where they engage on their terms, express their experience in their own language, build meaningful alliances and engage in 
alternative forms of political action. But most importantly, it is essential to recognise that elements of the taken-for-granted political process may be disconnected from the political. social and economic realities of young people's lives. There is a clear challenge for future research in this area to expand the focus beyond existing perspectives of the relationship between eivic and political engagement and 'mainstream' media, and include new and emerging forms within both fields.

\section{REFERENCES}

Amadeo, J., Torney-Purta, J., Lehmann, R., Husfeldt. V., \& Nikolova, R. (2002). Citi knowledge and

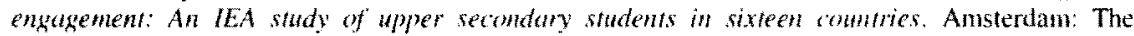
Intemational Association for the Evaluation of Fducational Achievement (It A).

Baldi, S., Perie, M, Skidmore, D. Greenberg, E. Hahn, C. \& Nelson, D. (2001). What demormy means to nimh-graders: U.S. resuls from the intermational IEA Civic Educahon study. Washington D.C.: U.S. Deparment of Education, National Center for Education Statistics.

Bennett, A. (2000). Popular music and yoult culure. London: MacMillan.

Biddle, D., Croce, N., LeQueux, S., Rowe. D.. \& Stevenson, D. (2000). Yomy People's Atitudes to Trade Unions: A study prepared for the Newastle Tiades Hall Coundi, Enployment Stulies Centre, University of Newcastle. Callaghan, NSW

Buckingham, D. (1999). Young People, Polihs and New's Media: beyond polital socialisation. Oxford Revien of Edutahon. $25(1$ \& 2)171-184.

Burgmann, V. (2003). Power, Profit and Protest: Atstralih sotid monements and globalisetion, Allen and Unwin, Crows Nest, NSW.

Burton, L. (2000). The Options Generation: A Discussion of Yaumg Australicm s Media Use. Austrohion Sireen Eductitin, Issue 22. Autumn 2000, pp.32-41.

Castles, S. (2004). Young Voters. Who Hewtx 'en?' Jolm Howard reminly doesn't. The Age. Monday April $19,9$.

Civics Expert Group. (1994). Whereas the people ... Civios and Cinzenship Edataiom. Canberra Australian Government Printing Service.

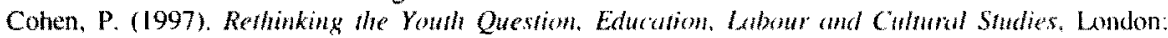
MacMillan.

Cohen, S. (1987). Folk Devils and Moral Pomic;: The Creatiom af he Mods and Rockers, $3^{\text {ts }}$ Edition. Oxford: Basil Blackwell.

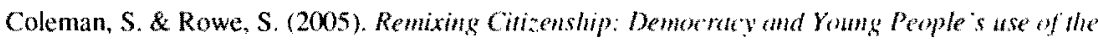
Internet, London: Carnegie Young People Initiative.

Comer, J, \& Pels, D. (Eds, (2003). Media and the Restyling of Palitics, London: Sage

CYPU. (2002). Young people and polinic: A repmot an the vote shot? Project. London: Children and Young People's Unit.

Dahlgreen, P. (2003). Reconliguring Civic Culture in the New Media Milieu. In J. Corner \& D. Pels. (Eds.) Media and the Restyling of Polinic: Consumers, Celebnity and Cymicism, Sage London.

Das, S. (2004). Vote 1, The Age. Wednesday Augusi 25.

Davis, M. (1997). Gangland: culural eliks and the new kenerationalism. Allen and Unwin. St.Leonards: NSW.

Dwyer, P. \& Wyn, J. (2001). Youth. Eduration and Risk: Fanting the Future. London: Routledge/Falmer.

Ellingsen, P. 2000. Don't call us a gencration, The Melbowme Age, Extra. May 6. 2000. pp 1.4\& 5.

Evans, V. \& Sternberg, J. (1999). Young People, Politics and Television Current Affairs in Australia in Ausiralia's Public Intellertual Fonm. 63,195.197.

Fahmy, E. (2003). A Disconnected Generation?: Encouraging Young People's Political Participation in the UK. Youth \& Policy. 81, 1-20. 
Fyle. 1. (2004). Civics and Citizenship Education in Australia: Are young people really discovering democracy? Unpublished Paper Presentation at Edacation and Social Action Conference 2004, Centre for Populat Education. University of Technology, Sydney. $6^{\text {th }}$ to $8^{\text {th }}$ December.

Goot. M. (2002). Distrustful, discnehanted and disengaged? Public opinion on politics, politicians and the parties: an historical perspective. In D. Burchell, \& A Leigh, (Eds.) (2002). The Prince's New Chatha: Why do Australians dishke their peliticians? Sydney UNSW Press.

Hamm, D. (2000). Learning Denoeracy is more than just leaming about Democracy, Connet, No. 122. April, pp. 4-6.

Harris. A. (2004). Future Gin, wong when in the wenty-firt cenury. New York: Routledge.

Harris, T. (2003). Anxious agitutors, The Australian, $28^{\text {b }}$ March, 15.

Henn. M. Weinstein. M. \& Forrest. S. (2005) - Uninterested Youth?: Young People's Attitudes towards Party Politics in Britain. Polinical Studies, 2005, Vol.53, pp \$56-578.

Howland, L., \& Bethell, M. (2002). Logged off?: How ICT can connest young people and politics, London: Demos.

Hudson, P. (2004). Meet Jess. candidate with a difference. The Stmdity Age, April 4, 9.

Kerr. D. Cleaver, E. Ireland, E. \& Blenkinsop, S. (2003). Citizenship education longitudinat sudy: Fint rousectiolit surey 2001.2002 (No. RR416). Notingham: National Foundation for Educational Research and Department for Education and Skills.

Kimberlee, R.H. (2002). Why don I British Young People Vote at General Elecions? Journal of Youth Simfies. $5(1), 85-98$.

King, A. (2005). Don't know, don't care. The Daty Telegraph, London, March 7.

Koffel, C. (2003). Globalisation of Youth Activism and Human Rights. In J. Arvanitakis, (Ed.) Highly Afferted. Rorely Comsidered: The International Youh Parliament Commission's Report on the Impats of Giwbalisation on Youmg People. Sydney: Oxfan.

Lesko, N. (2001). Act Your Age! A Culund Conthuchin of Adolescence. New York: RoutledgeFalmer.

Males, M. (1999). Framing Ymut: Tet Myth about the Next Generution, Maine: Common Courage Press.

Mannheim. K. (1952). Essars in the Sulblogy of Kumledge. London.

Manning, B., Ryan, R. (2004). Youth and citizenship: A repont for the National Youth Research Scheme, Canberra: Australian Government Department of Family and Community Services on behalf of National Youth Affairs Research Scheme (NYARS).

Margolis, M. \& Resnick, D. (2000). Politic's as Ustut: the cyberspace 'Revolution', Sage: London.

McAllister, 1. (1998). Civic Education and Political Knowledge in Australia. Australian Journal of Polition Sritince. $33(1), 7-23$.

McGaughey. M., \& Ayers, M. D. (Eds) (2003). Cybertivism: Online Activism in Theory und Practice. London: Routledge.

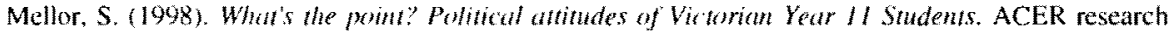
monograph No 53. Melboume: The Australian Council for Educational Research (ACER).

Mellor, S. Kennedy. K. J. \& Greenwood, L. (2002), Cinzenship and demoraty: Australian sudents knowledge and beliefs. The IEA civio edacation study of fourteen year olds. Camberwell: The Australian Council for Educational Rescarch Ltd.

Merrington, L. (2004). Here's a generation wanting to be heard, SAGE. August 31 .

Millar. R. (2004). Top local government job goes to 24-year-old, The Age. Friday August 27, 5.

Milner, H. (2005). Are Young Canadians becoming Political Dropouls?: A Comparative Perspective.

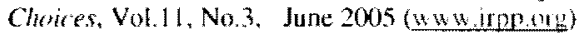

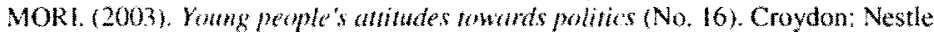

NetRatings Austraha 2005, kidsmline@home; Intenet ure in Austrollan homes, Sydney: Australian Broadeasting Authority and Netalen Limited.

Neuman, W. R. (1998). The Global Impact of New Technologies. In D. Graber, D. McQuail, \& P. Norris, (Eds, The Pollics of News The News of Pultics, Washington D.C: CQ Press

Nguyen, K. Boulton, M.. \& Millar, R. (2004). At 23, Clare the Mayor nakes Australian History, The Age, Saturday August 28.10.

Norris. P. (2003). Kommg People \& Political Artivism: From the Politics of Lovalties to the Politics of Chore? Repon for the Council of Europe Symposium: Young people and democratic institutions: from disillusionment to participation, Strasbourg. 
Olander, M. (2003). How young people express their political views. Fan Sheet. The Center for Information \& Research on Civic Learning and Engagement.

O'Neill, P. (2004). Young patriots do not trust pollies, Herild Sum, September 14.

Protyniack, N. (2004). Bantett backs teen bisexual for Senate, Herwd Sun, September 13, 4.

Radford, B. (2003). Media Mythmakers: how joumtalists, artivists and advertisers mislead us, New York: Prometheus Books.

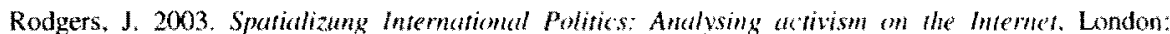
Routledge.

Sa, R. (2004). Some young people are lazy. The Tommo Sun. June 3.

Scott, A. \& Street, J. (2001). From media politics to e-protest? The use of popular culture and new media in parties and social movements. In F. Webster (Ed.) Culure and Politics in the holomation Age: A new politics, London: Routledge.

Smith, T. L., Smith. G. H., Boler, M., Kempton. M. Ormond, A. Chueh, H., \& Wactord, R. (2002). "Do you guys hate Aucklanders too"" Youth: voicing differences from the rural heartland, Jommal of Rurul Studies, 18, 179-178.

Tarabay, J. (2003), Australian police arrest protesters as anti-war demonstration tums violent. The Asseciated Press, $26 \mathrm{March}$.

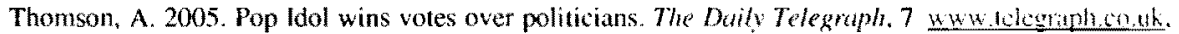
accessed $30^{\text {th }}$ May $2005,1,00 \mathrm{pm}$.

Van de Donk, W. Loader, B. D. Nixon, P. G. \& Ruch, D. (Eds.) (2004). Cuberprotest: New mediti. citizens and social movements, London: Routledge.

Woodcock, A, (2005), Reality TV beats politics. The Seotsmom, 7 March, www stotsmancenn, accessed $30^{\text {th }}$ May 2005, $1.00 \mathrm{pm}$

Wyn, J. (2005). Adult stereorypes of young people's communications. In A. Williams and C. Thurlow.

(Eds). Communication in Adolescence: Perspershes on Language and Social Interatian in the Teenage Years, New York: Peter Lang.

Wyn, J., \& White, R. (1997). Remmking Youth, London: Sagz. 


\section{University Library}

\section{- M M N E R VA A gateway to Melbourne's research publications}

Minerva Access is the Institutional Repository of The University of Melbourne

Author/s:

Edwards, K;Wyn, J

Title:

Young Activists Making the News:The Role of the Media in Youth Political and Civic Engagement

Date:

2007-01-01

Citation:

Edwards, K. \& Wyn, J. (2007). Young Activists Making the News:The Role of the Media in Youth Political and Civic Engagement. Saha, L (Ed.). Print, M (Ed.). Edwards, K (Ed.). Youth and Political Participation, (1), pp.113-132. BRILL.

Persistent Link:

http://hdl.handle.net/11343/30698 